\title{
Primary seed dispersal by a sigmodontine rodent assemblage in a Peruvian montane forest
}

\section{Catherine Teresa Sahley ${ }^{*, 1}$, Klauss Cervantes ${ }^{\dagger}$, Edith Salas ${ }^{\dagger}$, Diego Paredes ${ }^{\ddagger}$, Victor Pacheco ${ }^{\dagger}, \S$ and Alfonso Alonso ${ }^{\#}$}

\author{
* Andean and Marine Biodiversity Monitoring and Assessment Program, Center for Conservation and Sustainability, Smithsonian Conservation Biology Institute, 9099 \\ Woodcrest Dr., Brecksville, OH 44141, USA \\ $\dagger$ †epartamento de Mastozoología, Museo de Historia Natural, Universidad Nacional Mayor de San Marcos, Av. Arenales 1256, Lima 14, Lima, Peru \\ ¥ Laboratorio de Florística, Departamento de Dicotiledóneas, Museo de Historia Natural, Universidad Nacional Mayor de San Marcos, Av. Arenales 1256, Lima 14, Lima, \\ Peru \\ $\S$ Instituto de Ciencias Biológicas 'Antonio Raimondi', Facultad de Ciencias Biológicas, Universidad Nacional Mayor de San Marcos, Av. Venezuela s-n, Lima 1, Lima, \\ Perú \\ \# Center for Conservation and Sustainability, Smithsonian Conservation Biology Institute, National Zoological Park, 110 Jefferson Drive SW, MRC 705, Washington, DC \\ 20013, USA \\ (Received 7 October 2015; revised 15 January 2016; accepted 16 January 2016)
}

\begin{abstract}
We examined quantity and quality components of primary seed dispersal for an assemblage of sigmodontine rodents in a high-elevation montane tropical forest in Peru. We collected faecal samples from 134 individuals belonging to seven rodent species from the subfamily Sigmodontinae (Cricetidae) over a 2-y period. We conducted seed viability tests for seeds found in faecal samples. We identified seeds from eight plant families (Bromeliaceae, Annonaceae, Brassicaceae, Ericaceae, Melastomatacae, Myrtaceae, Rosaceae, Solanaceae), nine genera and 13 morphospecies. The most abundant seeds belonged to Gaultheria sp. 1 (46\% of total) and Miconia sp. 1 ( $31 \%$ of total), while the most viable seeds belonged to Greigia sp. ( $84 \%$ viability) and Guatteria sp. ( $80 \%$ viability). We utilized relative rodent abundance, seed species diversity, seed abundance and seed viability per rodent species to calculate an index of rodent disperser effectiveness, and found that Thomasomys kalinowskii was the most effective disperser, followed by Akodon torques, Calomys sorellus, Thomasomys oreas, Oligoryzomys andinus and Microryzomys minutus. Plant genera dispersed by sigmodontine rodents overlapped more with bird- and terrestrial-mammal-dispersed plants than with bat-dispersed plants. Future neotropical seed dispersal studies should consider small rodents as potential seed-dispersers, especially in tropical habitats where small-seeded, berry-forming shrubs and trees are present.
\end{abstract}

Key Words: frugivory, Peru, rodents, seed dispersal, Sigmodontinae, tropical montane forest

\section{INTRODUCTION}

In neotropical rain forests, seed dispersal by rodents has been shown to play an important role in plant reproduction via scatterhoarding, seed caching and/or secondary seed dispersal (Forget 1990, 1992; Forget \& Milleron 1991, Forget et al. 2002, Jansen et al. 2012). Rodents shown to disperse seeds of neotropical plants via these mechanisms are generally medium- to large-bodied, and consume fruit and/or seeds of canopy tree species (Adler \& Kestell 1998, Dittel et al. 2015, Forget 1990,

\footnotetext{
${ }^{1}$ Corresponding author. Email: ctsahley@gmail.com
}

1991, 1992; Haugaasen et al. 2010, Hoch \& Adler 1997, Smythe 1989). Small-bodied rodents, on the other hand, are widely considered to be seed predators (Demattia et al. 2004, Denslow \& Moermond 1982, Grenha et al. 2010, Griscom et al. 2007, Ostfeld et al. 1997, Pinto et al. 2009). Because of their influence on seed survivorship and seedling recruitment, several authors have called for inclusion of small rodents in guild/community studies of seed dispersal, but mostly to investigate their influence via seed predation (Demattia et al. 2004, Grenha et al. 2010). However, recent evidence for the neotropical rodent subfamily Sigmodontinae (Cricetidae) indicates that several species consume fruit and/or pass intact seeds 
in diverse neotropical habitats such as the montane forests in Peru (Noblecilla \& Pacheco 2012, Sahley et al. 2015), scrub habitats in Chile (Meserve 1981) and the Atlantic forests in Brazil (Vieira et al. 2003). Despite these findings, only one published account for cricetid rodents $(<100 \mathrm{~g})$ noted primary seed dispersal occurring via the digestive tract by Necromys lasiurus (formerly Bolomys lasiurus) after consumption of Miconia albicans fruit (Magnusson \& Sanaiotti 1987). Data on diet of small-bodied rodents and their potential for primary seed dispersal are therefore limited (Sahley et al. 2015).

Determining the role that small-bodied $(<100 \mathrm{~g})$ rodents might play in seed dispersal is crucial, given the importance of dispersal for plant reproductive success (Dalling et al. 2002, Howe \& Smallwood 1982, Wunderle 1997), re-establishment of plants in disturbed ecosystems (Medellin \& Gaona 1999, Parrotta et al. 1997, Tabarelli \& Peres 2002, Wunderle 1997), and the ubiquity of small rodents in neotropical habitats (Voss \& Emmons 1996). During a study examining potential impacts on small-rodent populations due to construction of a natural gas pipeline through a montane tropical forest, Sahley et al. (2015) found that seven species of sigmodontine rodent had intact seeds present in their faecal samples. In this study we tested the following hypotheses: (1) small rodents belonging to the subfamily Sigmodontinae (Cricetidae) have viable seeds in their faeces and function as seed dispersers; (2) based on a previous diet study (Sahley et al. 2015) the genus Thomasomys would disperse a greater diversity and abundance of seeds as well as seeds with a higher viability, therefore species belonging to this genus would be the most effective seed dispersers at the site; and (3) small rodent-dispersed plant families and genera would be more similar to those dispersed by birds than by bats.

\section{METHODS}

\section{Study site}

Our study site was located near Chiquintirca, department of Ayacucho, in the province of La Mar $\left(13^{\circ} 03^{\prime} 34^{\prime \prime} \mathrm{S}\right.$, $73^{\circ} 42^{\prime} 25^{\prime \prime} \mathrm{W}$ ), Peru. It is near the upper limit of montane forests of the Apurimac River valley ranging in altitude from 3200 to $3500 \mathrm{~m}$ asl. This area is categorized as pluvial montane subtropical forest (Instituto Nacional de Recursos Naturales 1995), upper montane pluvial forest of the yungas (Josse et al. 2003) and the Apurimac river valley montane forest ecotone (Langstroth et al. 2013). Vegetation consisted of a mosaic of tropical forest dominated by Polylepis spp. co-occurring with tropical shrubs (Langstroth et al. 2013, Servat et al. 2013). Rainfall at the site in 2011 and 2012 ranged from $30 \mathrm{~mm}$ in June to $388 \mathrm{~mm}$ in February 2012 (Sahley et al. 2015).

\section{Rodent captures and sample collection}

In 2011 and 2012, we used nine trapping grids $20 \times$ $150 \mathrm{~m}$ in size to live-trap rodents, following the protocol outlined in Pacheco et al. (2013). Each grid was made up of two parallel lines separated by 15-20 m each, and each line had 16 capture stations $10 \mathrm{~m}$ apart. Each station consisted of two Sherman traps that were $7.6 \times$ $8.9 \times 22.9 \mathrm{~cm}$. When possible, one of the Sherman traps was placed on a branch or shrub of a tree, 1-2 $\mathrm{m}$ above ground. Traps were baited and opened in the late afternoon and checked the following morning. In 2011, one trapping session was conducted in October and another in November (just prior to the rainy season) and in 2012 one trapping session was conducted in May (just after the rainy season). Traps were left open for a total of four nights in each session, for a total capture effort of 6912 trap nights. Captured rodents were identified to species, age class and weighed before being tagged and released.

Faecal pellets in each trap were collected and placed in labelled aluminium paper for storage. All faecal samples were transported in a cooler with silica gel to reduce humidity and stored at $0^{\circ} \mathrm{C}$.

\section{Plant species richness and reference material}

We collected leaves, stems, fruits and their seeds in 2012 to establish a reference collection for seed identification. All material was deposited in the Herbarium of the Universidad Nacional Mayor de San Marcos Natural History Museum. We used Servat et al. (2013) and Sahley et al. (2015) for plant identifications.

\section{Seed identification and quantification}

We placed 12 seeds from each aluminium packet in a $140 \times 20-m m$ Petri dish. We used distilled water to disaggregate faecal pellets and locate seeds. We used a $20 \times$ Leica RX stereoscope to determine seeds to family, genus and morphospecies when possible using our reference collection and identification keys found in Caceres (2004), Cornejo \& Janovec (2010), Gentry (1993), Ponte (1988) and Rios et al. (2004).

All seeds were photographed with a 1-mm grid paper placed below a Petri dish. Seed length was measured with a 1-mm grid paper placed below a Petri dish. We utilized the program Image J (www.ImageJ.nih.gov) to determine the length for seeds smaller than $1 \mathrm{~mm}$. We calculated the mean and standard deviation for seed length in our samples. 


\section{Seed viability}

We assessed seed viability using a $1 \%$ solution of tetrazolium. This test allows for determination of cellular respiration, which turns the seed embryo tissues a scarlet red colour and allows for an efficient estimate of germination capacity (ISTA 1996). In most cases, we determined viability for a minimum of 10 seeds per plant and per rodent species. We were unable to conduct viability test for Rubiaceae sp. 1 and we tested only one seed for Myrteola sp. To conduct viability tests, we made a small cut in the seed coat on the side opposite from the embryo. The seed was soaked in distilled water for $24 \mathrm{~h}$. We then removed the distilled water and we added the tetrazolium solution and soaked the seeds in complete darkness for an additional $24 \mathrm{~h}$. We then removed the seed coat to evaluate viability via embryo examination. We scored the embryo as viable only when it was scarlet red; if it was partially coloured, pink, or not coloured at all we classified the seed as non-viable. Because partially coloured or pink seeds can sometimes be viable (ISTA 1996), our viability analysis is conservative and may underestimate the proportion of viable seeds.

\section{Analysis of data}

We calculated the relative abundance of each rodent species by dividing the number of individuals captured per species by the total number of rodents captured for all species combined. We utilized 12 faecal pellets per individual rodent captured to quantify the total number of seeds for each species of plant and rodent; this allowed us to standardize the relative seed quantity estimates across rodent taxa. We calculated the mean and standard deviation of seed abundance in faecal samples per individual for each rodent species and the mean and standard deviation of seed number per sample (one sample $=12$ faecal pellets) for each plant species.

We calculated the proportional abundance of seeds dispersed by each rodent species by dividing the total number of seeds found for each rodent species by the total number of seeds found for all rodent species combined. The proportion of plant species diversity for each rodent species was calculated by dividing the total number of plant species found for each rodent species by the total number of plant species in all rodent species combined. The proportion viability of plant species for each rodent species was calculated by dividing the total number of scarlet-coloured seeds for each plant species per rodent species by the total number of seeds evaluated for viability for that plant species. The total combined seed viability for each rodent species was calculated by adding the number of all viable seeds and dividing this value by the total number of seeds evaluated. Total seed viability for plant species was calculated by dividing the total number of viable seeds for each plant species by the total number of seeds evaluated.

A Kruskal-Wallis test was calculated to examine differences in frequency distributions among plant species abundance in faecal samples across rodent species and also for differences in frequency distributions among plant species abundance in faecal samples across plant species. We calculated a chi-square statistic to examine differences in proportion seed viability by plant species for which we had $\mathrm{n}>10$ viability tests, as well as a chi-square statistic to test for differences in proportion seed viability among rodent species.

We calculated an index of disperser effectiveness for each species of rodent by utilizing the following equation:

$$
\begin{aligned}
& \text { Disperser effectiveness } \\
& \quad=\text { Relative abundance each rodent species } \\
& \times \text { proportion intact seeds in faecal samples } \\
& \times \text { proportion number plant species in samples } \\
& \times \text { proportion viable seeds } \times 100
\end{aligned}
$$

Statistical analyses were performed using SPSS version 21 .

\section{RESULTS}

\section{Rodent captures}

We captured and released a total of 134 rodents from seven species belonging to the subfamily Sigmodontinae (Cricetidae) in 2011-2012. These were Akodon torques (Thomas, 1917) $(n=49)$; Calomys sorellus (Thomas 1900) ( $n=20)$; Microryzomys minutus (Tomes, 1860) $(n=5)$; Oligoryzomys andinus (Osgood, 1914) $(\mathrm{n}=3)$; Thomasomys kalinowskii (Thomas, 1894$)(n=34)$; T. oreas Anthony, 1926 ( $n=21)$; and T. aureus (Tomes 1860) $(n=2)$.

\section{Plant families and species}

We found seeds of a total of eight plant families, nine genera and 13 morphospecies in faecal samples collected in 2011-2012. Plant families and genera recorded include Annonaceae (Guatteria sp.), Brassicaceae (Brassicaceae sp. 1), Bromeliaceae (Greigia sp.), Ericaceae (Gaultheria sp. 1 and G. sp. 2), Melastomataceae (Miconia sp. 1 and M. sp. 2), Myrtacae (Myrteola sp. 1), Rosaceae (Rubus sp. 1) and Rubiaceae (Rubiaceae sp. 1 and sp. 2). We found intact seeds and/or evidence of fruit pulp in faecal samples in all species of rodent. For this study, we only found fruit pulp in the faecal samples of T. aureus and 
Table 1. Mean ( \pm SD) length of seeds in rodent faecal samples for 2011-2012, Chiquintirca, Ayacucho, Peru. $\mathrm{n}=$ sample size. Seed size was very small in all cases.

\begin{tabular}{llcc}
\hline Family & Species & $\mathrm{n}$ & Mean seed length $(\mathrm{mm})$ \\
\hline Bromeliaceae & Greigia sp. & 5 & $3.60 \pm 0.43$ \\
Annonaceae & Guatteria sp. & 12 & $4.43 \pm 0.50$ \\
Brassicaceae & Brassicaceae sp. 1 & 56 & $0.64 \pm 0.07$ \\
Ericaceae & Gaultheria sp. 1 & 55 & $0.63 \pm 0.09$ \\
Ericaceae & Gaultheria sp. 2 & 20 & $0.56 \pm 0.06$ \\
Melastomataceae & Miconia sp. 1 & 75 & $0.84 \pm 0.08$ \\
Melastomataceae & Miconia sp. 2 & 31 & $0.78 \pm 0.09$ \\
Myrtaceae & Myrteola sp. & 9 & $1.83 \pm 0.07$ \\
Rosaceae & Rubus sp. & 12 & $2.58 \pm 0.11$ \\
Rubiaceae & Rubiaceae sp. 1 & 12 & $2.58 \pm 0.11$ \\
& Rubiaceae sp. 2 & 2 & $0.84 \pm 0.04$ \\
Solanaceae & Solanaceae sp. 1 & 18 & $1.67 \pm 0.12$ \\
Solanaceae & Solanaceae sp. 2 & 17 & $2.53 \pm 0.02$ \\
\hline
\end{tabular}

Table 2. Total and mean seed abundance \pm SD for plant species recorded in 12 faecal samples per rodent, Chiquintirca, Ayacucho Peru, 2011-2012. Plant species are listed in order of abundance.

\begin{tabular}{lccc}
\hline Species & Total number seeds in samples & Proportion seeds of total & Mean \pm SD seed number per sample (range) $n=132$ \\
\hline Gaultheria sp. 1 & 2158 & 0.46 & $16.34 \pm 25.05(0-145)$ \\
Miconia sp. 1 & 1459 & 0.31 & $11.05 \pm 27.04(0-220)$ \\
Brassicaceae sp. 1 & 351 & 0.08 & $2.66 \pm 21.7(0-223)$ \\
Gaultheria sp. 2 & 225 & 0.03 & $1.70 \pm 6.52(0-39)$ \\
Greigia sp. & 202 & 0.04 & $1.53 \pm 6.35(0-42)$ \\
Miconia sp. 2 & 167 & 0.035 & $1.27 \pm 7.64(0-75)$ \\
Rubiaceae sp. 2 & 33 & 0.007 & $0.25 \pm 2.87(0-33)$ \\
Rubus sp. & 30 & 0.006 & $0.23 \pm 1.80(0-17)$ \\
Guatteria sp. & 10 & 0.002 & $0.076 \pm 0.87(0-10)$ \\
Myrteola sp. & 6 & 0.001 & $0.045 \pm 0.37(0-3)$ \\
Solanaceae sp. 1 & 6 & 0.001 & $0.045 \pm 0.36(0-4)$ \\
Solanaceae sp. 2 & 6 & 0.001 & $0.045 \pm 0.36(0-4)$ \\
Rubiaceae sp. 1 & 1 & 0.0002 & $0.008 \pm 0.09(0-1)$ \\
All seeds & 4654 & 1.00 & $35.3 \pm 38.2(0-234)$ \\
\hline
\end{tabular}

could not conduct seed viability tests. Average seed length found in samples ranged from $0.56 \mathrm{~mm}$ to $4.43 \mathrm{~mm}$, with Gaultheria sp. 2 having the smallest seeds and Greigia sp. having the largest (Table 1).

\section{Seed abundance and distribution across samples}

We found a total of 4654 seeds in rodent faecal samples, with a mean \pm SD number of $35.3 \pm 38.2$ seeds per sample (Table 2). The distribution of seed abundance in samples by plant species was significantly different (Kruskal-Wallis test, $\left.\chi^{2}=24.2, \mathrm{df}=5, \mathrm{P}<0.05\right)$. The Ericaceae ( $\mathrm{n}=6$ species of rodent), Melastomataceae $(\mathrm{n}=$ $3)$ and Rosaceae $(n=3)$ were the best represented families consumed by rodent species, followed by Myrtaceae and Solanaceae $(\mathrm{n}=2)$, and Brassicaceae and Bromeliaceae $(\mathrm{n}=1)$. Gaultheria sp. 1 (Ericaceae) not only had the highest total number of seeds in faecal samples, but also the highest mean number of seeds per faecal sample; in addition seeds were also present in all six rodent species examined (Table 2). Miconia sp. 1 (Melastomataceae) had the second highest abundance and mean number per sample, while Gaultheria sp. 2 had considerably lower total and mean abundance values (Table 2). Miconia sp. 1 and Gaultheria sp. 2 occurred in faecal samples from three species of rodent. Gaultheria sp. 2 and the remaining morphospecies have mean values of less than three seeds per sample and are found in one to two species of rodent.

\section{Seed viability}

We found that all plant species tested (except for Myrteola sp.) had viable seeds in faecal samples. Differences in proportion seed viability among plant species (excluding Myrteola sp., Solanaceae sp. 2 and Rubiaceae sp. 1 from 
Table 3. Total intact seeds found in faecal samples, relative abundance of rodent species, proportion relative abundance of intact seeds, proportion species richness found in samples and proportion of viable seeds (total number of seeds tested) for each rodent species at Chiquintirca, Ayacucho, Peru 2011-2012. The disperser effectiveness index is the relative contribution of each rodent species to effective seed dispersal and is the product of the relative abundance of each rodent species $\times$ proportion abundance of seeds $\times$ proportion species richness of seeds $\times$ proportions of viable seeds $\times 100$.

\begin{tabular}{|c|c|c|c|c|c|c|}
\hline Rodent species & $\begin{array}{l}\text { Total intact seeds in } \\
12 \text { faecal samples per } \\
\text { individual }\end{array}$ & $\begin{array}{l}\text { Relative abundance } \\
\text { rodent species }\end{array}$ & $\begin{array}{l}\text { Proportion } \\
\text { abundance } \\
\text { of seeds }\end{array}$ & $\begin{array}{l}\text { Proportion species } \\
\text { richness of seeds }\end{array}$ & $\begin{array}{l}\text { Proportion of } \\
\text { viable seeds }\end{array}$ & $\begin{array}{l}\text { Disperser } \\
\text { effectiveness } \\
\text { index }\end{array}$ \\
\hline $\begin{array}{l}\text { Akodon torques } \\
\mathrm{n}=49\end{array}$ & 1096 & 0.37 & 0.24 & 0.38 & $0.14(394)$ & 0.47 \\
\hline $\begin{array}{l}\text { Calomys sorellus } \\
\mathrm{n}=20\end{array}$ & 1099 & 0.15 & 0.24 & 0.15 & $0.57(130)$ & 0.31 \\
\hline $\begin{array}{l}\text { Microryzomys minutus } \\
\mathrm{n}=5\end{array}$ & 29 & 0.04 & 0.006 & 0.08 & $0(15)$ & 0 \\
\hline $\begin{array}{l}\text { Oligoryzomys andinus } \\
\mathrm{n}=3\end{array}$ & 36 & 0.02 & 0.007 & 0.08 & $0.2(20)$ & 0.0003 \\
\hline $\begin{array}{l}\text { Thomasomys } \\
\text { kalinowskii } \\
\mathrm{n}=34\end{array}$ & 1723 & 0.25 & 0.37 & 0.92 & $0.43(467)$ & 3.8 \\
\hline $\begin{array}{l}\text { Thomasomys oreas } \\
\mathrm{n}=21\end{array}$ & 671 & 0.16 & 0.14 & 0.38 & $0.12(210)$ & 0.10 \\
\hline
\end{tabular}

the analysis due to $n<10)$ were significant $\left(\chi^{2}=229\right.$, $\mathrm{n}=1231, \mathrm{df}=9, \mathrm{P}<0.001)$. Greigia sp. $(\mathrm{n}=110)$ and Guatteria sp. $(\mathrm{n}=10)$, only found in T. kalinowskii, had the highest viability values, $80 \%$ to $84 \%$ respectively. Gaultheria sp. 1 was found in samples from every rodent species except for M. minutus. Overall viability was 30\% $(\mathrm{n}=535)$, with $21 \%(\mathrm{n}=200)$ viability for seeds found in A. torques, $70 \%(\mathrm{n}=110)$ for $C$. sorellus, $0 \%(\mathrm{n}=15)$ for M. minutus, $20 \%(\mathrm{n}=20)$ for O. andinus, $32 \%(\mathrm{n}=90)$ for T. kalinowskii, and $14 \%(\mathrm{n}=100)$ for T. oreas. Gaultheria sp. 2 seeds had a total viability of $27 \%(\mathrm{n}=90)$ with viability values of $27 \%(\mathrm{n}=30)$ for $A$. torques, $25 \%(\mathrm{n}=$ $20)$ for $C$. sorellus, and $28 \%(\mathrm{n}=40)$ for $T$. kalinowskii. Seeds of this species were not found in samples from $M$. minutus, O. andinus or T. oreas. Miconia sp. 1 had a total seed viability of $15 \%(\mathrm{n}=374)$, with $4 \%$ viability $(\mathrm{n}=$ $164)$ for $A$. torques, $27 \%(\mathrm{n}=150)$ for $T$. kalinowskii, and $13 \%(n=60)$ for T. oreas. Seeds of this species were not found in C. sorellus, M. minutus or O. andinus. Miconia sp. 2 were found only in T. kalinowskii and T. oreas, and had an overall viability of $7.5 \%(\mathrm{n}=40)$ with a viability of $0 \%(\mathrm{n}=10)$ for T. kalinowskii, and $10 \%(\mathrm{n}=30)$ for $\mathrm{T}$. oreas. Rubus sp. had a total viability of $55 \%(\mathrm{n}=20)$, and seeds were found only for T. kalinowskii. Myrteola sp. had $0 \%$ viability but our very small sample size $(n=1)$ for T. kalinowskii precludes us from making reliable viability estimates. Seeds belonging to the Brassicaceae sp. 1 were found only in T. kalinowskii and had a total viability of $20 \%$ ( $n=30)$. Rubiaceae sp. 2 seeds had a total viability of $9 \%(n=11)$, with 1 seed out of 1 viable for T. kalinowskii and 0 seeds out of 10 for T. oreas. Solanaceae sp. 1 also had a total viability of $9 \%(n=11)$, with 1 seed of 1 viable for T. kalinowskii and 0 seeds out of 10 viable for T. oreas.
Solanaceae sp. 2 was found only in T. kalinowskii and had a total viability of $75 \%(n=4)$. We were unable to conduct a viability test for Rubiaceae sp. 1 .

\section{Rodent species and seed disperser effectiveness}

We found that the distributions of plant species in faecal samples varied significantly across rodent species (Kruskal-Wallis test, $\chi^{2}=24.2$, df $=12, \mathrm{P}<0.01$ ). Total seed abundance in faecal samples was greatest for T. kalinowskii $(\overline{\mathrm{x}} \pm \mathrm{SD}=50.7 \pm 57.8)$, followed by $C$. sorellus $(\bar{x} \pm \mathrm{SD}=55.0 \pm 36.5)$, A. torques $(\bar{x} \pm \mathrm{SD}=22.4$ $\pm 18.7)$, T. oreas ( $\bar{x} \pm \mathrm{SD}=32.0 \pm 20.1)$, O. andinus $(\bar{x} \pm$ $\mathrm{SD}=12.0 \pm 4.0)$ and M. minutus $(\bar{x} \pm \mathrm{SD}=5.8 \pm 1.8)$ in descending order (Table 3$)$. Thomasomys kalinowskii had the highest proportion plant species richness represented in faecal samples with 12 species of plants occurring in faecal samples (Table 3). Thomasomys oreas faecal samples contained five species of plants, followed by A. torques ( 3 species), C. sorellus (2 species), M. minutus and O. andinus (1 species each).

Although containing a relatively low seed species diversity in samples, $C$. sorellus had a relatively high seed abundance, and the greatest percentage of viable seeds in faecal samples (57\%) followed closely by T. kalinowskii (43\% viability; Table 3 ). The remaining species of rodents had from $12 \%$ to $20 \%$ viable seeds, except for M. minutus, which had no viable seeds in faecal samples. Differences in total seed viability among rodent species were statistically significant $\left(\chi^{2}=177, \mathrm{n}=1236, \mathrm{df}=5, \mathrm{P}<0.001\right)$.

An index for seed disperser effectiveness for each rodent species, calculated using relative rodent abundance, 
proportional seed abundance, plant species diversity and seed viability, showed that the combination of these variables indicates that $T$. kalinowskii is the most effective seed disperser at this montane-forest site. Akodon torques and C. sorellus are the second and third most effective seed dispersers. Thomasomys oreas and O. andinus are the fourth and fifth most effective seed dispersers whereas M. minutus did not disperse viable seeds (Table 3).

\section{DISCUSSION}

We found that small sigmodontine rodents $(<100 \mathrm{~g})$ are primary seed dispersers in the high-elevation tropical montane forest studied. Five of six species of rodents passed intact and viable seeds of 13 morphospecies, eight families and nine genera of plants. Our estimate of primary seed dispersal occurrence is likely conservative because a longer-term study examining diet found seeds from 17 morphospecies and nine families in faecal samples of all seven species at the same study site (Sahley et al. 2015). Primary seed dispersal for small rodents of the cricetid family has been noted only once, for Necromys lasiurus, which passed viable Miconia albicans seeds through its digestive tract (Brewer \& Rejmánek 1999). Consumption of fruit and/or passage of intact seeds by small sigmodontine rodents has been noted for these and other species in various habitats such as the Brazilian Atlantic forest (Vieira et al. 2006), Chilean temperate rain forest (Meserve et al. 1988) and montane forest in Peru (Noblecilla \& Pacheco 2012, Sahley et al. 2015), however except for the N. lasiurus study (Brewer \& Rejmánek 1999) seed viability and/or contribution to seedling establishment was not examined.

Our study site is comprised of approximately 172 species and morphospecies in 94 genera and 54 families of plants that comprise a mosaic of forest and shrub habitat near the upper limit of montane forest (Sahley et al. 2015, Servat et al. 2013). Thefamilies identified in faecal samples are known to produce berries and in one case, capsules. Small-seeded berries are produced by the Bromeliaceae (Benzing 2000, Will \& Zizka 1999), Melastomataceae (Renner 1989), Rubiaceae (Bremer \& Eriksson 2008), Myrtaceae (Pizo 2002), Ericaceae (Eriksson 2008, Stiles 1980), Rosaceae (Stiles 1980) and Solanaceae (BarbosaAlbuquerque et al. 2006) while the Brassicaceae produce capsules (Hall et al. 2011). Krebs et al. (2010) found that berries are important food resources for North American small rodents and influence their population dynamics; thus it is not surprising that small neotropical rodents would also feed on small-seeded fruits (Sahley et al. 2015).

\section{Seed disperser effectiveness}

Our study shows the genera Thomasomys, Akodon and Calomys as important seed dispersers in the tropical montane forest studied. In accord with our hypothesis, the genus Thomasomys was responsible for most seed dispersal, with T. kalinowskii being the most effective disperser for the studied plant community. Thomasomys spp. may exhibit semi-arboreal habits; nests for T. aureus have been found in trees (Brito et al. 2012), and evidence of arboreal activity for T. oreas have been recorded (Pacheco unpubl. data), although such data do not exist as of yet for T. kalinowskii. Further research on the genus Thomasomys including effects of gut passage on seed viability, foraging behaviour and comparative dispersal effectiveness among species is warranted.

Akodon torques, reported as insectivorous (Noblecilla \& Pacheco 2012, Solari 2007), consumed fruit and passed intact seeds at our study site, including a diverse and large quantity of insects. While it consumes fruits of fewer species than the genus Thomasomys, because of its high relative abundance and passage of viable seeds for Gaultheria spp. and Miconia sp. 1, it had the second highest effective disperser index of this rodent assemblage.

Calomys sorellus, a rodent often considered to be insectivorous and commonly found in high Andean grassland habitat (Pizzimenti \& de Salle 1980) was found to include fruit in its diet at our study site (Sahley et al. 2015). The proportion of intact seeds (belonging to the genus Gaultheria) and seed viability in faecal samples was relatively high. This is significant as we found that $C$. sorellus was the only rodent to cross the $25-\mathrm{m}-$ wide area cleared during pipeline construction during early restoration efforts before taller shrubs were reestablished (Sahley unpubl. data). Thus, C. sorellus may have contributed to dispersing seeds to the 25-m-wide pipeline right of way during early stages of vegetation restoration.

Oligoryzomys andinus and M. minutus both had intact Gaultheria sp. 1 seeds in faecal samples. The relative abundance of both species was low in this rodent assemblage. For $O$. andinus seed viability was low to medium while for M. minutus seed viability was zero. Overall, these two species contribute the least to seed dispersal compared with others in this rodent assemblage.

In summary, T. kalinowskii was the most effective disperser in montane forest and shrub areas because of high seed abundance, diversity, and viability values; it also disperses seeds of two genera that are not found in other rodent species at our site. Akodon torques was important primarily because of its high abundance, and C. sorellus because of its high viability for one plant genus and its ability to cross the recovering pipeline right of way prior to the re-establishment of vegetation cover. 


\section{Fruit consumption and seed dispersal of plant families at the study site}

The rodent assemblage at our site consumed fruits and dispersed seeds from families and genera that are also consumed and dispersed by other taxonomic groups, but these overlapped more with terrestrial mammals and birds than with bats. For example, Greigia sp. (Bromeliaceae) is a bromeliad that grows near the ground; its fruits are consumed by the Andean bear (Tremarctos ornatus; Troya et al. 2004) as well as by T. kalinowskii. Greigia fruits are also utilized for human consumption (HornungLeoni 2006, Will \& Zizka 1999). Seed viability of Greigia sp. was high for T. kalinowskii (84\%), but we did not record Greigia sp. in faecal samples of other rodent genera.

Gaultheria spp. (Ericaceae) are shrubs that produce berries that are consumed by birds, the spectacled bear (Tremarctos ornatus) and Andean fox (Lycalopex culpaeus); Rivadeira-Canedo (2008) showed that seeds of this genus were viable after bird and mammal consumption. We found Gaultheria sp. 1 seeds in all species of rodents studied and found viable seeds in four of the six rodent species examined, while Gaultheria sp. 2 was consumed by four of six rodent species examined.

Miconia spp. are primarily known for being consumed and dispersed by birds (Levey 1990, Loiselle \& Blake 1999, Wheelwright et al. 1984). Miconia spp. seeds were relatively abundant in samples from this rodent assemblage, with three of six rodent species found to pass viable seeds. The Miconia spp. have previously been reported to pass as viable through the digestive tract of the sigmodontine rodent Necromys lasiurus (Magnusson \& Sanaiotti 1987).

Guatteria spp. are generally found as small- to mediumsized trees and produce berries. These are consumed by birds (Snow 1981, Wheelwright et al. 1984) as well as spider monkeys (Ateles spp.) and the woolly monkey, Lagothrix lagotricha (Link \& Di Fiore 2006, Stevenson 2000). We found Guatteria sp. (Annonaceae) seeds in relatively low abundance and only in T. kalinowskii. However, viability of these seeds was high.

Species belonging to the Rubiaceae in the neotropics have fruits that have been recorded as being consumed by small passerines (Loiselle et al. 1995, Snow 1981, Tabarelli \& Peres 2002). We recorded two unidentified morphospecies in the Rubiaceae samples from the genus Thomasomys.

Rubus spp. have been recorded as being consumed and dispersed by birds (Wheelwright et al. 1984), as have other species within the Rosaceae (Herrera \& Jordano 1981). One species belonging to the genus Rubus (Rosaceae) was found in samples, although relative seed abundance was low. While Rubus sp. seeds were viable in T. kalinowskii samples, sample size was too low to make any firm conclusion on the importance of T. kalinowskii to its reproductive ecology.

Both bats and birds are reported to consume and/or disperse fruits and seeds belonging to the family Solanaceae (Caceres \& Moura 2003, Galindo-Gonzales et al. 2000, Loayza et al. 2006, Snow 1981, Wheelwright et al. 1984). Seeds belonging to Solanaceae sp. 1 and sp. 2 were found only in samples belonging to the genus Thomasomys.

The Brassicaceae were represented by one morphospecies found in faecal samples belonging to T. kalinowskii; viability of seeds was $20 \%$, suggesting a role for $T$. kalinowskii as a seed disperser. The Brassicaceae, unlike the other families identified in samples, form two-valved jointed and non-jointed capsules instead of berries (Hall et al. 2011) and have been reported to primarily utilize passive dispersal modes such as wind and water (Willis et al. 2014).

\section{Implications for seed-dispersal ecology}

In many studies of neotropical forests, primary or secondary seed-disperser taxa have been identified as bats, birds or medium to large rodents primarily belonging to the Dasyproctidae and Echimyidae. Our study suggests that in habitats where sigmodontine rodents consume small-seeded fruits in areas with shrubs or small to medium-sized trees, it is likely that they are serving as primary seed dispersers in montane forests, transition zones, as well as tropical montane habitats in early successional stages, and areas that are being restored or recovering from deforestation. Thus, we recommend that for a more complete understanding of plant reproductive ecology in montane forests, sigmodontine rodents should be included in frugivore and seed-dispersal studies.

While we identified the presence of intact seeds and seed viability in faecal samples of sigmodontine rodents, we recognize that additional components of seed dispersal, such as quality of deposition sites, germination rates and seedling establishment are necessary to gather a more complete picture of small-rodent contributions to seedling recruitment. We hope that additional studies will continue to elucidate the relationships between sigmodontine rodents, their food plants, and their role as seed dispersers in neotropical forests.

\section{ACKNOWLEDGEMENTS}

We thank the government of Peru (Dirección General Forestal y de Fauna, Ministerio de Agricultura) for granting us permits to conduct the study (No. 440-2009AG-DGFFS-DGEFFS, No. 344-2010-AG-DGFFS-DGEFFS, No. 144-2012-AG-DGFF-DGEFFS). We are indebted to 
Edgar Rengifo, Cecilia Barriga, Maria Peralta, Oscar Centty, David Figueroa, Juan Tito and Wendy Calderon for assistance in the field, and to Edith Arias, Pamela Nina and Giovana Vadillo for assistance in the laboratory. Ornella Sissa and Karim Ledesma provided logistical support. We thank the Smithsonian Institution and PERU LNG for financial support. This is publication \# 37 from the Peru Biodiversity Program, Center for Conservation and Sustainability, Smithsonian Conservation Biology Institute.

\section{LITERATURE CITED}

ADLER, G. H. \& KESTELL, D. W. 1998. Fates of Neotropical tree seeds influenced by spiny rats (Proechimys semispinosus). Biotropica 30: 677-681.

BENZING, D. H. 2000. Bromeliaceae: Profile of an adaptive radiation. Cambridge University Press, Cambridge.

BARBOSA-ALBUQUERQUE, L., VELÁZQUEZ, A. \& MAYORGASAUCEDO, R. 2006. Solanaceae composition, pollination and seed dispersal syndromes in Mexican mountain cloud forest. Acta Botanica Brasilera 20:599-613.

BREMER, B. \& ERIKSSON, O. 2008. Evolution of fruit characters and dispersal modes in the tropical family Rubiaceae. Biological Journal of the Linnean Society 47:79-95.

BREWER, S. \& REJMÁNEK, M. 1999. Small rodents as significant dispersers of tree seeds in a Neotropical forest. Journal of Vegetation Science 10:165-174.

BRITO, J., TESKA, W. R. \& OJALA-BARBOUR, R. 2012. Descripción del nido de dos especies de Thomasomys (Cricetidae) en un bosque alto-andino en Ecuador. Therya 3:263-268.

CACERES, N. C. \& MOURA, M. O. 2003. Fruit removal of a wild tomato, Solanum granulosoleprosum Dunal (Solanaceae) by birds, bats, and non-flying mammals in an urban Brazilian environment. Revista Brasileira de Zoologia 20:519-522.

CACERES, P. 2004. Caracterización dendrológica de las especies de los géneros Ficus y Cecropia (Moraceae) en el valle de Chanchamayo (Junín-Perú). Thesis to fufill requirements for the title of Forestry Engineer. Universidad Nacional Agraria la Molina-UNALM, Lima, Peru.

CORNEJO, F. \& JANOVEC, J. 2010. Seeds of Amazonian plants. Princeton University Press, Princeton. 192 pp.

DALLING, J. W., MULLER-LANDAU, H. C., WRIGHT, S. J. \& HUBBELL, S. P. 2002. Role of dispersal in the recruitment limitation of neotropical pioneer species. Journal of Ecology 90:714-727.

DEMATTIA, E. A., CURRAN, L. M. \& RATHCKE, B. J. 2004. Effects of small rodents and large mammals on Neotropical seeds. Ecology 85:2161-2170.

DENSLOW, J. S. \& MOERMOND, T. C. 1982. The effect of accessibility on rates of fruit removal from tropical shrubs: an experimental study. Oecologia 54:170-176.

DITTEL, J. W., LAMBERT, T. D. \& ADLER, G. H. 2015. Seed dispersal by rodents in a lowland forest in central Panama. Journal of Tropical Ecology 31:403-412.
ERIKSSON, O. 2008. Evolution of seed size and biotic seed dispersal in angiosperms: paleoecological and neoecological evidence. International Journal of Plant Science 169:863-870.

FORGET, P. M. 1990. Seed dispersal of Vouacapoua americana (Caesalpiniaceae) by caviomorph rodents in French Guiana. Journal of Tropical Ecology 6:459-468.

FORGET, P. M. 1991. Scatterhoarding of Astrocaryum paramaca by Proechimys in French Guiana: comparison with Myoprocta exilis. Journal of Tropical Ecology 32:155-167.

FORGET, P. M. 1992. Post-dispersal predation and scatterhoarding of Dipteryx panamensis (Papilionaceae) seeds by rodents in Panama. Oecologia 94:255-261.

FORGET, P. M. \& MILLERON, T. 1991. Evidence for secondary seed dispersal by rodents in Panama. Oecologia 87:596-599.

FORGET, P. M., HAMMOND, D. S., MILLERON, T. \& THOMAS, R. 2002. Seasonality of fruiting and food hoarding by rodents in neotropical forests: consequences for seed dispersal and seedling recruitment. Pp. 241-256 in Levey, D. J., Silva, W. R. \& Galletti, M. (eds). Seed dispersal and frugivory: ecology, evolution and conservation. CABI, Wallingford.

GALINDO-GONZALEZ, J., GUEVARA, S. \& SOSA, V. J. 2000. Bat and bird generated seed rains at isolated trees in pastures in a tropical rainforest. Conservation Biology 14:1693-1703.

GENTRY, A. H. 1993. A field guide to the families and genera of woody plants of northwest South America (Colombia, Ecuador, Peru). Conservation International, Washington, DC. 920 pp.

GRENHA, V., MACEDO, M. V., PIERES, A. S. \& MONTEIRO, R. F. 2010. The role of Cerradomys subflavus (Rodentia, Cricetidae) as seed predator and disperser of the palm Allagoptera arenaria. Mastozoologia Neotropical 17:61-68.

GRISCOM, H. P., KALKO, E. K. V. \& ASHTON, M. S. 2007. Frugivory by small vertebrates within a deforested, dry tropical region of Central America. Biotropica 39:278-282.

HALL, J. C., TISDALE, T. E., DONOHUE, K., WHEELER, A., AL-YAHYA, M. A. \& KRAMER, E. M. 2011. Convergent evolution of a complex fruit structure in the tribe Brassiceae (Brassicaceae). American Journal of Botany 98:1989-2003.

HAUGAASEN, J. M. TUCK, HAUGAASEN, T., PERES, C. A., GRIBEL, R. \& WEGGE, P. 2010. Seed dispersal of the Brazil nut tree (Bertholletia excelsa) by scatter-hoarding rodents in a central Amazonian forest. Journal of Tropical Ecology 26:251-262.

HERRERA, C. M. \& JORDANO, P. 1981. Prunus mahaleb and birds: the high efficiency seed dispersal system of a temperate fruiting tree. Ecological Monographs 51:203-218.

HOCH, G. A. \& ADLER, G. H. 1997. Removal of black palm (Astrocaryum standleyanum) seeds by spiny rats (Proechimys semispinosus). Journal of Tropical Ecology 13:51-58.

HORNUNG-LEONI, C. T. 2006. Avances sobres usos etnobotanicos de la Bromeliaceae en Latinoamerica. Boletin Latinoamericano y del Caribe de plantas Medicinales y Aromaticas 10:297-314.

HOWE, H. \& SMALLWOOD, J. 1982. Ecology of seed dispersal. Annual Review of Ecology and Systematics 13:201-208.

INRENA (INSTITUTO NACIONAL DE RECURSOS NATURALES). 1995. Mapa ecológico del Perú. Mapa y guía explicativa. Instituto Nacional de Recursos Naturales, Ministerio de Agricultura, Lima. 
ISTA (INTERNATIONAL SEED TESTING ASSOCIATION). 1996. International Rules for Seed testing. Seed Science and Technology 21:1288.

JANSEN, P. A., HIRSCH, B. T., EMSENS, W. J., ZAMORA-GUTIERREZ, V., WIKELELSKI, M. \& KAYS, R. 2012. Thieving rodents as substitute dispersers of megafaunal seeds. Proceedings of the National Academy of Sciences USA 109:12610-12615.

JOSSE, C., NAVARRO, P., COMER, R., EVANS, D., LANGENDOEN, M., FELLOWS, M., KITTEL, G., MENARD, M., PYNE, M., SCHULZ, K., SNOW, K. \& TEAGUE, J. 2003. Ecological systems of Latin America and the Caribbean: a working classification of terrestrial systems. NatureServe, Arlington.

KREBS, C. K., COWCILL, K., BOONSTRA, R. \& KENNY, A. J. 2010. Do changes in berry crops drive population fluctuations in small rodents in the southwestern Yukon? Journal of Mammalogy 91:500-509.

LANGSTROTH, R., DALLMEIER, F., CASARETTO, C. \& SERVAT, G. P. 2013. Ecological landscape units across the Eastern Andean Valleys, High Andes, and Pacific Watershed Region of the Peru LNG Megaproject. Pp. 10-20 in Alonso, A., Dallmeier, F. \& Servat, G. P. (eds). Monitoring biodiversity: lessons from a trans-Andean Megaproject. Smithsonian Institution Scholarly Press, Washington, DC.

LEVEY, D. 1990. Habitat dependent fruiting behavior of an understory tree, Miconia centrodesma and tropical treefall gaps as keystone habitats for frugivores in Costa-Rica. Journal of Tropical Ecology 6:409-420.

LINK, A. \& DI FIORE, A. 2006. Seed dispersal by spider monkeys and its importance in the maintenance of neotropical rain-forest diversity. Journal of Tropical Ecology 22: 235-246.

LOAYZA, A., RIOS, R. \& LARREA-ALCAZAR, D. 2006. Disponibilidad de recurso y dieta de murciélagos frugivoros en la Estacion Biologica Tunquini, Boliva. Ecologia en Bolivia 41:7-23.

LOISELLE, B. \& BLAKE, J. 1999. Dispersal of melastome seeds by fruiteating birds of tropical forest understory. Ecology 80:330-336.

LOISELLE, B. A., SORK, V. A., NASON, J. \& GRAHAM, C. 1995. Spatial genetic structure of a tropical understory shrub, Psychotria officinalis (Rubiaceae). American Journal of Botany 82:14201425.

MAGNUSSON, W. E. \& SANAIOTTI, T. M. 1987. Dispersal of Miconia seeds by the rat Bolomys lasiurus. Journal of Tropical Ecology 3: 277278.

MEDELLIN, R. A. \& GAONA, O. 1999. Seed dispersal by bats and birds in forest and disturbed habitats of Chiapas, Mexico. Biotropica 31:478485.

MESERVE, P. L. 1981. Trophic relationships among small mammals in a Chilean semiarid thorn scrub community. Journal of Mammalogy 62:304-314.

MESERVE, P. L., LANG, B. K., \& PATTERSON, B. D. 1988. Trophic relationships of small mammals in a Chilean temperate rainforest. Journal of Mammalogy 69:721-730.

NOBLECILLA, M. C. \& PACHECO, V. 2012. Dieta de roedores sigmodontines (Cricetidae) en los bosques montanos tropicales de Huanuco, Peru. Revista Peruana de Biologia 19:317-322.

OSTFELD, R. S., MANSON, R. H. \& CANHAM, C. D. 1997. Effects of rodents on survival of tree seed and seedlings invading old fields. Ecology 78:1531-1542.
PACHECO, V., SALAS, E., BARRIGA, C. \& RENGIFO, E. 2013. Small mammal diversity in disturbed and undisturbed montane forest in the area of influence of the Peru LNG Pipeline, Apurimac River Watershed, Ayacucho. Peru. Pp. 90-100 in Alonso, A., Dallmeier, F. \& Servat, G. P. (eds). Monitoring biodiversity: lessons from a Trans-Andean megaproject. Smithsonian Institution Scholarly Institute Press, Washington, DC.

PARROTTA, J. A., HENRY KNOWLES, O. \& WUNDERLE, J. M. 1997. Development of floristic diversity in 10-year-old restoration forests on a bauxite mined site in Amazonia. Forestry Ecology and Management 99:21-42.

PINTO, S. R., SANTOS, A. M. \& TABERELLI, M. 2009. Seed predation by rodents and safe sites for large-seeded trees in a fragment of the Brazilian Atlantic forest. Brazilian Journal of Biology 69:763-771.

PIZZIMENTI, J. J. \& DE SALLE, R. 1980. Dietary and morphometric variation in some Peruvian rodent communities: the effect of feeding strategy on evolution. Biological Journal of the Linnean Society 13:263285.

PIZO, M. A. 2002. The seed dispersers and fruit syndromes of Myrtaceae in the Brazilian Atlantic forest. Pp. 129-143 in Levey, D. J., Silva, W. R. \& Galetti, M. (eds). Seed dispersal and frugivory: ecology, evolution and conservation. CABI, Wallingford.

PONTE, M. 1998. Inventario y análisis florístico de la estructura del bosque. Pp. 43-65 in Wust, W. (ed). La Zona Reservada de Tumbes, biodiversidad y diagnóstico socioeconómico. The John D. and Catherine C. MacArthur Foundation-Fondo Nacional por las Áreas Protegidas por El Estado (PROFONANPE), Lima, Peru.

RENNER, S. Z. 1989. A survey of reproductive biology in Neotropical Melastomatacae and Memecylaceae. Annals of the Missouri Botanical Garden 76:496-518.

RIOS, M., GIRALDO, P. \& CORREA, D. 2004. Guía de frutos y semillas de la cuenca media del río Otún. Fundación EcoAndina.

RIVADEIRA-CANEDO, C. 2008. Estudio del oso andino (Tremarctos ornatus) como dispersor legítimo de semillas y elementos de su dieta en la región de Apolobamba-Bolivia. Ecologia en Bolivia 43:2939.

SAHLEY, C. T., CERVANTES, K., PACHECO, V., SALAS, E., PAREDES, D. \& ALONSO, A. 2015. Diet of a sigmodontine rodent assemblage in a Peruvian montane forest. Journal of Mammalogy 96: 10711080.

SERVAT, G. P., FERIA, T. P., HURTADO, N., MENDOZA, W. \& ALCOCER, R. 2013. Potential distribution and habitat characterization of Atlapetes melanopsis (Aves: Emberizidae) in a montane forest ecotone of the Apurimac river valley. Pp. 141-153 in Alonso, A., Dallmeier, F. \& Servat, G. P. (eds). Monitoring biodiversity: lessons from a Trans-Andean megaproject. Smithsonian Institution Scholarly Press, Washington, DC.

SMYTHE, N. 1989. Seed survival in the palm Astrocaryum standleyanum: evidence for dependence upon its seed dispersers. Biotropica 21:5056.

SNOW, D. 1981. Tropical frugivorous birds and their food plants: a world survey. Biotropica 13:1-14.

SOLARI, S. 2007. Trophic relationships within a highland rodent assemblage from Manu National Park, Cusco, Peru. Pp. 225-240 in Kelt, D. A., Lessa, E. P., Bravo, J. S. \& Patton, J. L. (eds.). The 
quintessential naturalist: honoring the life and legacy of Oliver P. Pearson. University of California Press, Berkeley.

STEVENSON, P. R. 2000. Seed dispersal by woolly monkeys (Lagothrix lagothricha) at Tinigua National Park, Colombia. American Journal of Primatology 50:275-289.

STILES, E. W. 1980. Patterns of fruit presentation and seed dispersal in bird-disseminated woody plants in the eastern deciduous forest. American Naturalist 116: 670-688.

TABARELLI, M. \& PERES, C. 2002. Abiotic and vertebrate seed dispersal in the Brazilian Atlantic forest. Implication for forest regeneration. Biological Conservation 106:165-176.

TROYA, V., CUESTA, F. \& PERALVO, M. 2004. Food habits of Andean bears in the Oyacachi River Basin, Ecuador. Ursus 15:57-60.

VIEIRA, E. M., PIZO, M. A. \& IZAR, P. 2003. Fruit and seed exploitation by small rodents of the Brazilian Atlantic forest. Mammalia 67:1-7.

VIEIRA, E. M., PAISE, G. \& MACHADO, H. D. 2006. Feeding of small rodents on seeds and fruits: a comparative analysis of 3 species of rodents of the Araucaria forests, southern Brazil. Acta Theriologica 51:311-318.

VOSS, R.H.\&EMMONS, L. H. 1996. Mammalian diversity in Neotropical lowland rainforests: a preliminary assessment. Bulletin of the American Museum of Natural History 230:1-115.

WHEELWRIGHT, N., HABER, W., MURRAY, K. \& GUINDON, C. 1984. Tropical fruit eating birds and their food plants: a survey of a Costa Rican lower montane forest tropical fruit-eating birds and their food plants. Biotropica 16:173-192.

WILL, B. \& ZIZKA, G. 1999. A review of the genus Greigia Regel (Bromeliaceae) in Chile. Havard Papers in Botany 4:225-240.

WILLIS, C. G., HALL, J. C., RUBIO, R. R., WANG, T. Y. \& DONOHUE, K. 2014. Diversification and the evolution of dispersal ability in the tribe Brassicaceae (Brassicaceae). Annals of Botany 114:16751686.

WUNDERLE, J. M. 1997. The role of animal seed dispersal in accelerating native forest regeneration on degraded tropical lands. Forestry Ecology and Management 99:223-235. 